\title{
THE REVIEW OF RUSSIA'S ECONOMIC LEGISLATION IN OCTOBER $2015^{1}$
}

\author{
I.Tolmacheva, Yu.Grunina
}

In October 2015, the following main amendments were introduced into the legislation: the procedure for carrying out monitoring by the Ministry of Labor and Social Protection of the Russian Federation of the situation on the labor market by constituent entities of the Russian Federation for the purpose of maintaining of the optimal balance of labor resources was determined; the Central Bank of Russia prepared the information on procedures for and grounds and consequences of bankruptcy of individuals.

\section{Resolutions of the Government of the Russian Federation}

Resolution No.1106 of 15 October 2015 of the Government of the Russian Federation on Approval of the Rules of Carrying Out of Monitoring of the Situation on the Labor Market of the Russian Federation by Constituent Entities of the Russian Federation.

The monitoring includes collection of the data on the situation on the labor market of the Russian Federation by constituent entities of the Russian Federation, processing and classification of the data, as well as the analysis of the situation on the labor market of the Russian Federation by constituent entities of the RF on the basis of the input data

Within the frameworks of the monitoring, the following indices are calculated:

- the level of social tensions on the labor market;

- the share of the attracted foreign workers in the total number of the gainfully employed population;

- the share of the attracted foreign workers in the total number of the gainfully employed population nationwide and by constituent entities of the Russian Federation.

In addition to the above, the monitoring permits to check indices which should not be exceeded by indices of the level of social tensions on the labor market set by the Ministry of Labor and Social Protection of the Russian Federation, as well as analyze the effect of foreign nationals working in the territory of the Russian Federation on the labor market.

\section{Instructions, Letters, Orders and Messages}

Information Message of 1 October 2015 of the Central Bank of Russia on Amendment of the Legislation as Regards Bankruptcy of Individuals.

1 The Review was prepared with assistance of the KonsultantPlus legal system.
From 1 October 2015, such amendments of the legislation as regulate the relations between debtorindividuals and creditors became effective.

In particular, the amendments deal with the following:

- Citizens have the right to refer to an arbitration court with a request to recognize them as bankrupt. In some cases, submission of such an application is mandatory for the debtor. A creditor in bankruptcy proceedings and authorized body have the right to refer to court, too;

- Bankruptcy cases are considered by an arbitration court at the place of residence of the citizen;

- In consideration of a bankruptcy case, such procedures as restructuring of debts, sale of the citizen's property and conclusion of an amicable settlement agreement are applied. If it is impossible to restructure the debt, the court takes a decision to recognize the citizen as bankrupt which situation entails the sale of the property. The procedure for sale of the property is set for the period of maximum 6 months;

- Participation of the financial manager in the individual's bankruptcy case is mandatory and paid for at the expense of that individual or creditor in bankruptcy proceedings;

- From the day of recognition by the court of the individual's application for bankruptcy as justified, financial penalties, as well as interests on the individual's all the obligations, except for current payments, cease to be accrued;

- Within 5 years from the beginning of completion of sales of the property or termination of proceedings in bankruptcy case, the individual is not in a position to take obligations under a loan agreement without the fact of his/her bankruptcy being specified. 